\title{
INNOVATIVE MODIFICATION OF TRADITIONAL BURGER
}

\author{
ABD-ELHAK, NASRA A., SAFAA E. ALI and NAHED L. ZAKI
}

Food Technology Research Institute, ARC, Giza

(Manuscript received 8 April 2014)

\begin{abstract}
This research aimed to increase the vegetables intake by using some healthy, cheaper and low calories nutrients in practical method, in processing of beef burgers in order to produce novel and healthier beef burgers at lower cost, without affecting cooking and sensory properties. The technology and characteristics of beef burger containing plant substitutes (cooked red radish and artichoke individually), at different levels (10, 20, 30,40 and $50 \%$ ) on the quality characteristics water holding capacity (WHC) and cooking measurements (cooking loss, cooking yield, cooking shrinkage and moisture retention) of beef burger patties were studied. The current results revealed that the sensory evaluation results indicated that color, texture and odor of beef burger blends with health benefits materials non significantly differences for the control sample.

The present work recommended that it should be incorporated of these promising healthy nutrients for production of beef burger.

Keywords: red radish- artichoke - beef burger - chemical composition- cooking measurements -sensory evaluation.
\end{abstract}

\section{INTRODUCTION}

Burgers are usually a feature of fast foods, most fast foods contain extremely high levels of trans fatty acids, which can lead to obesity ,type 2 diabetes and coronary disease, Studies have shown that the diets which rich in saturated fats and trans fats (like burger and fries meal) increase blood levels of LDL (low density lipoprotein) cholesterol that clogs the arteries. Individuals who eat fast food regularly had a much lower intake of fruits and vegetables, ( Zoraida et al.2011).

Fruits and vegetables are an important component of a healthy diet and, if consumed daily in sufficient amounts, could help prevent major diseases such as certain cancers. Vegetables are the excellent and cheaper source of minerals and contribute to the RDA (recommended dietary allowance) of these essential nutrients .Vegetable nutrition has widely drawn the attention of fitness conscious as well as food scientists alike for their proven health benefits. Meat products that contain dietary fibers are excellent meat substitutes due to their inherent functional and nutritional effects. Dietary fiber intake through meat substituted with fruits, vegetables and certain grains is associated with reductions in plasma and LDLcholesterol, reduce the risk of major dietary problems such as obesity, coronary 
diseases, diabetes, gastrointestinal disorders, including constipation, inflammatory bowel diseases etc (Schneeman, 1999).

Radish, (Raphanus sativus $\mathrm{L}$ ) is one of very low calorie root vegetables of Brassicaceae family which has been reputed for its benefic medicinal properties. Fresh root provides 16 calories per $100 \mathrm{~g}$. , nonetheless, they are a very good source of antioxidants, electrolytes, minerals, vitamins and dietary fiber. Radish contains iso thiocyanate anti-oxidant such as compound called sulforaphane. Studies suggest that sulforaphane has proven role against prostate, breast, colon and ovarian cancers by virtue of its cancer-cell growth inhibition, and cyto-toxic effects on cancer cells. Radish is very rich in roughage, i.e. indigestible carbohydrates. This facilitates digestion, retains water, cures constipation (one of the main causes for piles) and thus gives relief in piles. It is also very good for the liver and the stomach and it is a very good detoxifier too, that it is purifies blood. Fresh roots are rich in vitamin C (15 mg per $100 \mathrm{~g})$, Bansa,(2011).

The artichoke (Cynara scolymus L.) is a large thistle that belongs to the sunflower family. It is one of the highly nutritious vegetables available during the winter. Artichoke is low in calories and fat, but it is a rich source of dietary fiber, which helps to control constipation conditions, decrease bad or "LDL" cholesterol levels by binding to it in the intestines and help prevent colon cancer risks by preventing toxic compounds in the food from absorption. Artichoke contains bitter principles, cynarin and sesquiterpene-lactones, these compounds inhibit cholesterol synthesis and increase its excretion in the bile and thus, have overall cholesterol reduction in the blood. Fresh artichoke is an excellent source of vitamins and rich in phytonutrients and antioxidants. This helps to boost the body's immunity against diseases. It also promotes good health. These potent nutrients have been found helpful in the maintenance of healthy cells especially in cases of prostrate cancer because they inhibit the proliferation of the cancerous cells. Vincenzo et al. (2009).

The objective of this study was to evaluate the quality characteristics of beef burger formulated by partial substitution of beef meat with different level of both red radish and artichoke into beef burger production by replacing of meat on the quality physico-chemical, cooking measurements (cooking yield, cooking shrinkage, moisture retention, and cooking loss) and sensory characteristics of beef burger patties. 


\section{MATERIALS AND METHODS}

Materials:-

Artichoke (Cynara scolymus L.) and red radish,( Raphanus sativus $\mathrm{L}$ ) were purchased from the local market at Giza. Beef meat was purchased from the local butcher shop at Giza Governorate, Egypt. The meat was stored in a refrigerator at $5 \pm 1^{\circ} \mathrm{C}$ overnight, before experiment, other ingredients: spices, onion, starch , garlic , salt and refined sunflower oil were obtained from the local market at Giza.

-Methods:-

- Preparation of plant materials:-

Red radish and artichoke tubers were cleaned, washed, cut and boiled with sufficient amounts of water, for two minutes The plant materials cooled, drained and squeeze by hands to get rid of extra water. As for artichoke, it soaked in diluted lemon juice (acidic solution) to inhibit the activity of polyphenol oxidase as recommended by Tchone et. al. (2005). All such materials were milled with kitchen machine. Time of cooking (two minutes ) is very important, increasing time of cooking and ignore squeezing of the cooking materials lead to tinder juicy plant materials that affect the burger characteristics.

\section{Burger Preparation formulas:}

Eleven types of formulations were prepared by Experimental Kitchen, Food Technology Research Institute, Agricultural Research Center. Tested samples were formulated with both $0 \%$ (control) $, 10 \%, 20 \%, 30 \%, 40 \%$ and $50 \%$ of red radish and artichoke individually by replacing meat. The ingredient percentages of burger formulations are shown in Table (1). The ingredients of each formulated burger were homogenized in Braun Cutter Machine (CombiMax 700, USA), then from the homogenized meat mixture and processed into burger of about $80 \mathrm{gm}$ weight, $8 \mathrm{~cm}$ diameter. and $1 \mathrm{~cm}$ in thickness. 
Table 1. Ingredient of burger formulations $(\mathrm{g} / 100 \mathrm{~g})$.

\begin{tabular}{|l|c|c|c|c|c|c|c|c|}
\hline Ingredients & $\begin{array}{c}\text { Beef } \\
\text { meat }\end{array}$ & $\begin{array}{c}\text { Red } \\
\text { radish }\end{array}$ & Artichok & Spices & Onion & Garli & Starch & Salt \\
\hline Control & 76 & -- & - & 1 & 10 & 1 & 10 & 2 \\
\hline MR 10 & 68.4 & 7.6 & - & 1 & 10 & 1 & 10 & 2 \\
\hline MR 20 & 60.8 & 15.2 & - & 1 & 10 & 1 & 10 & 2 \\
\hline MR 30 & 53.2 & 22.8 & - & 1 & 10 & 1 & 10 & 2 \\
\hline MR 40 & 45.6 & 30.4 & - & 1 & 10 & 1 & 10 & 2 \\
\hline MR 50 & 38.0 & 38.0 & - & 1 & 10 & 1 & 10 & 2 \\
\hline MA 10 & 68.4 & - & 7.6 & 1 & 10 & 1 & 10 & 2 \\
\hline MA 20 & 60.8 & - & 15.2 & 1 & 10 & 1 & 10 & 2 \\
\hline MA 30 & 53.2 & - & 22.8 & 1 & 10 & 1 & 10 & 2 \\
\hline MA 40 & 45.6 & - & 30.4 & 1 & 10 & 1 & 10 & 2 \\
\hline MA 50 & 38.0 & - & 38.0 & 1 & 10 & 1 & 10 & 2 \\
\hline MR10 & $-10 \%$ & & -10 & & & \\
\hline
\end{tabular}

MR10 $=$ Meat $+10 \%$ Radish, MA10 $=$ Meat $+10 \%$ Artichoke

MR20 $=$ Meat $+20 \%$ Radish, MA20 $=$ Meat $+20 \%$ Artichoke

MR30 $=$ Meat $+30 \%$ Radish, MA30 $=$ Meat $+30 \%$ Artichoke

MR40 $=$ Meat $+40 \%$ Radish, $\quad$ MA40 $=$ Meat $+40 \%$ Artichoke

MR50 $=$ Meat $+50 \%$ Radish,$\quad$ MA50 $=$ Meat $+50 \%$ Artichoke

The prepared burger were packaged by individually in polyethylene film to help maintaining the shape of patties prior to freezing. The samples were frozen at $18^{\circ} \mathrm{C}$ prior to analysis.

\section{Cooking of beef burger samples :}

Samples of beef burger were cooked according to the method described by Ou and Mittal (2006), then cooking yield, moisture retention and shrinkage were determined according to ( El-Magoli et. al. 1996), while cooking loss was calculated according to the following equation :

Cooking loss $=[$ (weight of raw sample - weight of cooked sample $) \div$ weight of raw sample] $\times 100$. Using The method reported by Jama et al. (2008).

Cooking yield $(\%)=\frac{\text { Cooked weight }}{\text { Raw weight }} \times 100$.

\section{- Proximate chemical composition}

Moisture, protein, fat, fiber and ash contents of raw and cooked samples were determined according to the methods of A.O.A.C (2000). Total carbohydrates 
was calculated by the differences .All proximate composition experiments were performed in triplicate and expressed as $\mathrm{g} / 100 \mathrm{~g}$ of burger on fresh basis.

Mineral contents (zinc, iron, calcium, potassium, sodium, magnesium manganese and cupper) were determined using a Pye Unicum SP1900 Atomic Absorption Spectroscopy instrument (Perkin Elmer model 4100ZL) as described by AOAC (2000).

The caloric value was calculated using the following Atwater conversion factors: $9 \mathrm{K.cal} / \mathrm{g}$ of lipid, $4 \mathrm{K.cal} / \mathrm{g}$ of carbohydrate and $4 \mathrm{~K} . \mathrm{cal} / \mathrm{g}$ of protein (Frary and Johnson2005) .

\section{Water holding capacity (W.H.C.)}

Water holding capacity (W.H.C.) of meat tissues was measured according to the method described by Honikel (1998). The meat tissues $(0.3 \mathrm{~g})$ was carefully flattened in a glass plate and covered with shells filter paper (whatman No. 41) then pressed for $10 \mathrm{~min}$ using a mass of one $\mathrm{kg}$ weight. Two zones were formed on filter paper, their surface area was measured using planimeter. The W.H.C. was calculated as $\mathrm{cm}^{2} / 0.3 \mathrm{~g}$ by subtracting the area of the internal zone from that of the outer.

\section{Sensory evaluation:-}

The Sensory characteristics of the cooked burger samples were carried out by well trained 20 panelists of Food Technology Research Institute (FTRI). Panelists were asked to evaluate color, odor, texture, taste, tenderness, appearance and overall acceptability, of cooked samples according to the method described by American Meat Science Association (1995).

\section{Statistical analysis:}

Data for sensory evaluation, physical and chemical evaluation was subjected to analysis of variance (ANOVA) followed by Duncan's multiple range tests were carried out using SPSS computer program (SPSS, 1999).

\section{RESULTS AND DISCUSSION}

Data in Table (2) show that the moisture, crude protein, fat, carbohydrate, fiber and ash contents for fresh red radish were 92.9, $0.98,0.13,3.26,2.03$ and 0.7 versus $84.1,2.36,0.31,6.92,4.40$ and $0.91 \%$ for artichoke. These results are in agreement with those reported by, Zhao-liang et al. (2008) and Lutz et. al. (2011).

The obtained values of moisture content were slightly increased after cooking for both kinds. While, protein and fat contents in red radish were slightly decreased, also cooking process decreased the total carbohydrates in both red radish and artichoke. On the other hand, higher fiber content observed in cooked radish 
compared with the fresh one as shown in the same table. Fresh artichoke had higher fiber and ash content. (Vibe et al. 2013)

Table 2. Chemical composition of fresh and cooked red radish and artichoke materials (on fresh weight basis).

\begin{tabular}{|l|c|c|c|c|}
\hline \multirow{2}{*}{ Chemical Component \% } & \multicolumn{2}{|c|}{ Radish } & \multicolumn{2}{c|}{ Artichoke } \\
\hline \multirow{2}{*}{ Moisture } & raw & Cooked & Raw & Cooked \\
\cline { 2 - 5 } & $92.9^{\mathrm{b}}$ & $93.4^{\mathrm{a}}$ & $84.1^{\mathrm{b}}$ & $85.3^{\mathrm{a}}$ \\
\hline Crude protein & $0.98^{\mathrm{a}}$ & $0.87^{\mathrm{b}}$ & $2.36^{\mathrm{a}}$ & $1.91^{\mathrm{b}}$ \\
\hline Fat & $0.13^{\mathrm{a}}$ & $0.10^{\mathrm{b}}$ & $0.31^{\mathrm{a}}$ & $0.28^{\mathrm{b}}$ \\
\hline T. C.* & $3.26^{\mathrm{a}}$ & $2.51^{\mathrm{b}}$ & $6.92^{\mathrm{a}}$ & $6.43^{\mathrm{b}}$ \\
\hline Fiber & $2.03^{\mathrm{b}}$ & $3.65^{\mathrm{a}}$ & $4.40^{\mathrm{b}}$ & $5.4^{\mathrm{a}}$ \\
\hline Ash & $0.70^{\mathrm{a}}$ & $0.47^{\mathrm{b}}$ & $0.91^{\mathrm{a}}$ & $0.68^{\mathrm{b}}$ \\
\hline
\end{tabular}

T.C* $=$ Total carbohydrates calculated by difference

\section{Minerals content of fresh radish and artichoke:}

Data presented in Table (3) showed that the minerals (Zinc, iron, calcium, potassium, sodium, magnesium, manganese and cupper) contents of fresh and cooked red radish and artichoke.

Table 3. Mineral contents of fresh and cooked red radish and artichoke (calculated as $\mathrm{mg} / 100 \mathrm{~g}$ fresh sample)

\begin{tabular}{|l|l|l|l|l|l|l|l|l|}
\hline \multicolumn{1}{|c|}{ Minerals } & Zn & Fe & Ca & K & Na & Mg & Mn & Cu \\
\hline Faterials & $2.81^{\mathrm{a}}$ & $0.35^{\mathrm{a}}$ & $26.0^{\mathrm{a}}$ & $233^{\mathrm{a}}$ & $38.0^{\mathrm{a}}$ & $10.0^{\mathrm{a}}$ & $0.069^{\mathrm{a}}$ & $0.05^{\mathrm{a}}$ \\
\hline Cooked red radish & $2.63^{\mathrm{b}}$ & $0.28^{\mathrm{b}}$ & $23.72^{\mathrm{b}}$ & $228^{\mathrm{b}}$ & $36.8^{\mathrm{b}}$ & $8.6^{\mathrm{b}}$ & $0.062^{\mathrm{b}}$ & $0.04^{\mathrm{b}}$ \\
\hline Fresh artichoke. & $0.48^{\mathrm{a}}$ & $1.28^{\mathrm{a}}$ & $45.0^{\mathrm{a}}$ & $371^{\mathrm{a}}$ & $95.0^{\mathrm{a}}$ & $6.1^{\mathrm{a}}$ & $0.256^{\mathrm{a}}$ & $0.231^{\mathrm{a}}$ \\
\hline $\begin{array}{l}\text { Cooked } \\
\text { artichoke. }\end{array}$ & $0.42^{\mathrm{b}}$ & $1.22^{\mathrm{b}}$ & $41.7^{\mathrm{b}}$ & $366^{\mathrm{b}}$ & $91.5^{\mathrm{b}}$ & $5.83^{\mathrm{b}}$ & $0.251^{\mathrm{b}}$ & $0.229^{\mathrm{b}}$ \\
\hline
\end{tabular}

Data in table (3) showed that potassium represented the highest value of mineral content while manganese and cupper constituted the lowest value of both raw and cooked samples of red radish and artichoke. These results are in agreement with those obtained by López et. al. (1997) and Vincenzo et. al. (2009). Cooking process slightly decreased mineral contents in both fresh red radish and artichoke.

\section{Chemical composition of the produced burger:}

Data presented in Table (4) showed the major chemical constituents of beef burger sample. There is significant difference in moisture content of different beef burger blends and control. Moisture content of beef burger blends of red radish and 
artichoke was ranged from 48.27 to $62.58 \%$ and 46.03 to $68.73 \%$ respectively. Also, the same table showed that protein and fat content of control beef burger was 16.54 and $4.11 \%$ respectively .

The same table revealed that the changes in fiber and ash contents of all produced beef burger blends. The highest significant differences of fiber content in the beef burger blends compared to control sample. The high level of fiber in tested burger can be useful in decreasing cholesterol level in human ( Zoraida et al.2011), was due to the highest proportion of radish and artichoke ingredient in these blends. These results agree with Gedrovica and Karklina (2012), they reported that the addition of dried Jerusalem artichoke powder to pastry products changed their chemical parameters, increases their dietary fiber content, reduces energy value, and increases the nutritional value. The highest decreased of protein and fat was found in MR50 and MA50 , it represented $48,48.01,43.35$ and $54.1 \%$ respectively ,from the result in the same table, it could be noticed that, total carbohydrates content was high in control and treatments MR30, MR40, and MA 10 than the other treatments .

The same Table showed that significant differences in caloric values were found among all the burger blends. The highest amount was noticed in case of burger manufactured from control blend.

Table 4. Chemical composition of the beef burger blends (in fresh weight basis).

\begin{tabular}{|c|c|c|c|c|c|c|c|}
\hline Blends & Moisture & Protein & fat & Ash & Fiber & $\begin{array}{c}\text { Total } \\
\text { carbohydrates }\end{array}$ & $\begin{array}{c}\text { Caloric } \\
\text { value } \\
\text { K.cal } / 100 \mathrm{~g}\end{array}$ \\
\hline control & $41.44^{\prime}$ & $16.54^{\mathrm{a}}$ & $4.11^{a}$ & $0.86^{f}$ & $0.16^{k}$ & $36.88^{a}$ & $250.62^{\mathrm{a}}$ \\
\hline MR10 & $45.20^{k}$ & $13.52^{\mathrm{c}}$ & $3.22^{\mathrm{b}}$ & $0.95^{\mathrm{cd}}$ & $0.58^{\mathrm{j}}$ & $36.63^{b}$ & $229.51^{c}$ \\
\hline MR20 & $49.60^{\mathrm{h}}$ & $13.36^{d}$ & $2.92^{d}$ & $0.97^{\mathrm{ab}}$ & $0.94^{h}$ & $32.21^{d}$ & $208.56^{d}$ \\
\hline MR30 & $55.30^{\mathrm{e}}$ & $11.76^{f}$ & $2.67^{\mathrm{e}}$ & $0.92^{\mathrm{e}}$ & $1.34^{f}$ & $28.70^{\mathrm{e}}$ & $183.41^{\mathrm{f}}$ \\
\hline MR40 & $60.80^{d}$ & $10.18^{\mathrm{h}}$ & $2.41^{g}$ & $0.97^{\mathrm{ab}}$ & $1.75^{\mathrm{d}}$ & $24.50^{g}$ & $160.41^{h}$ \\
\hline MR50 & $62.58^{c}$ & $8.61^{j}$ & $2.13^{i}$ & $0.94^{d}$ & $2.14^{c}$ & $23.58^{i}$ & $147.85^{i}$ \\
\hline MA10 & $46.03^{j}$ & $13.67^{b}$ & $3.16^{c}$ & $0.95^{\mathrm{cd}}$ & $0.65^{i}$ & $35.56^{c}$ & $225.33^{b}$ \\
\hline MA20 & $54.06^{9}$ & $13.67^{b}$ & $2.11^{j}$ & $0.95^{\mathrm{cd}}$ & $1.17^{9}$ & $28.04^{f}$ & $185.74^{\mathrm{e}}$ \\
\hline MA30 & $58.58^{d}$ & $12.25^{\mathrm{e}}$ & $2.51^{f}$ & $0.96^{\mathrm{bc}}$ & $1.68^{\mathrm{e}}$ & $23.65^{\mathrm{h}}$ & $166.16^{9}$ \\
\hline MA40 & $63.10^{b}$ & $10.81^{9}$ & $2.18^{h}$ & $0.97^{\mathrm{ab}}$ & $2.18^{\mathrm{b}}$ & $20.84^{j}$ & $146.15^{\mathrm{j}}$ \\
\hline MA50 & $68.73^{a}$ & $9.37^{i}$ & $1.86^{k}$ & $0.98^{\mathrm{a}}$ & $2.72^{\mathrm{a}}$ & $16.36^{k}$ & $119.54^{k}$ \\
\hline \multicolumn{8}{|c|}{ 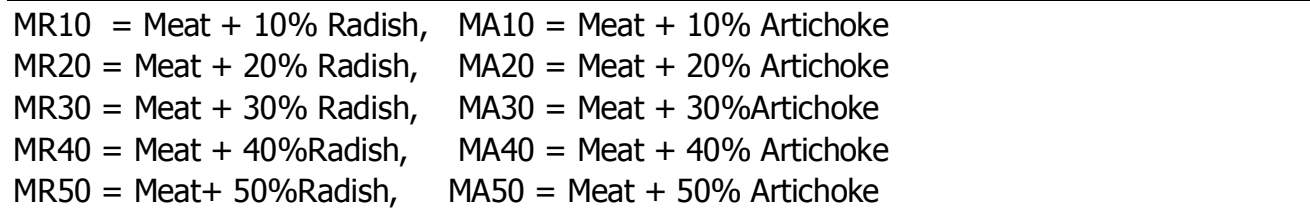 } \\
\hline
\end{tabular}

\section{Physical characteristics of beef burger samples}

Regarding cooking measurements (cooking yield, cooking shrinkage, moisture retention, cooking loss and water holding capacity) which are considered one of the 
most important physical quality changes occur in beef burgers during cooking process due to protein denaturation and releasing of fat and water from beef burger patties (Oroszvári et al. 2005). Therefore, the impact of incorporating of red radish artichoke alone at ratios of either $10,20,30,40$ and $50 \%$ from meat weight used in beef burger formulation on cooking measurements including cooking yield ,cooking shrinkage, moisture retention, cooking loss and water holding capacity of producing burger patties, compared to the control sample. The obtained results are tabulated in Table (5).

Table 5. Mean value of physicochemical criteria for experiments produced beef burger blends.

\begin{tabular}{|c|c|c|c|c|c|}
\hline Blends & $\begin{array}{c}\text { Moisture } \\
\text { retention\% }\end{array}$ & $\begin{array}{c}\text { cooking } \\
\text { shrinkage \% }\end{array}$ & WHC & $\begin{array}{c}\text { Cooking } \\
\text { loss } \%\end{array}$ & $\begin{array}{l}\text { Cooking } \\
\text { yield\% }\end{array}$ \\
\hline control & $39.10^{\mathrm{j}}$ & $21.02^{\mathrm{a}}$ & $1.10^{\mathrm{k}}$ & $13.64^{j}$ & $86.35^{\mathrm{a}}$ \\
\hline MR10 & $46.26^{\mathrm{e}}$ & $18.23^{\mathrm{b}}$ & $3.03^{h}$ & $16.54^{\mathrm{h}}$ & $83.41^{\mathrm{c}}$ \\
\hline MR20 & $46.72^{d}$ & $16.64^{c}$ & $3.33^{\mathrm{g}}$ & $20.31^{c}$ & $79.66^{f}$ \\
\hline MR30 & $47.31^{c}$ & $16.46^{d}$ & $3.52^{f}$ & $21.65^{\mathrm{b}}$ & $77.35^{9}$ \\
\hline MR40 & $47.92^{b}$ & $15.71^{\mathrm{e}}$ & $3.75^{d}$ & $19.42^{\mathrm{e}}$ & $76.57^{\mathrm{h}}$ \\
\hline MR50 & $49.54^{\mathrm{a}}$ & $15.12^{f}$ & $4.61^{c}$ & $19.27^{f}$ & $71.73^{\mathrm{k}}$ \\
\hline MA10 & $40.55^{i}$ & $10.14^{g}$ & $2.13^{j}$ & $16.23^{\mathrm{i}}$ & $83.76^{\mathrm{b}}$ \\
\hline MA20 & $41.33^{h}$ & $9.83^{h}$ & $2.83^{i}$ & $17.68^{g}$ & $82.32^{d}$ \\
\hline MA30 & $42.71^{9}$ & $9.50^{i}$ & $3.63^{\mathrm{e}}$ & $19.73^{d}$ & $79.85^{\mathrm{e}}$ \\
\hline MA40 & $45.02^{f}$ & $8.98^{\mathrm{j}}$ & $5.11^{\mathrm{b}}$ & $20.32^{c}$ & $74.64^{i}$ \\
\hline MA50 & $46.94^{d}$ & $8.54^{k}$ & $5.92^{\mathrm{a}}$ & $21.93^{a}$ & $72.45^{j}$ \\
\hline
\end{tabular}

MR10 = Meat $+10 \%$ Radish, MA10 $=$ Meat $+10 \%$ Artichoke

MR20 $=$ Meat $+20 \%$ Radish, MA20 $=$ Meat $+20 \%$ Artichoke

MR30 $=$ Meat $+30 \%$ Radish, MA30 $=$ Meat $+30 \%$ Artichoke

MR40 $=$ Meat $+40 \%$ Radish, $\quad$ MA40 $=$ Meat $+40 \%$ Artichoke

MR50 $=$ Meat $+50 \%$ Radish,$\quad$ MA50 $=$ Meat $+50 \%$ Artichoke

From the obtained results (Table 5), it could be noticed that, moisture retention of beef burger formulated with radish and artichoke were similar with the trend of cooking yield. The moisture retention was proportionally increased with the increment of fiber content in burger formulations.

Cooking yield was decreased in burger incorporated with red radish and artichoke. Control sample recorded the significant highest cooking yield (86.35\%). The cooking characteristics of control sample consider within the range the cooking characteristics of commercial burger, there were an inverse relationship between moisture retention and cooking yield with the addition levels of red radish and artichoke to the beef burger formulations. This is probably due to the inability of red 
radish and artichoke fiber to create a tridimensional matrix within the burgers due to the high moisture content. Adjusted cooking yields reflect the yields relative to the amount of beef meat used in the formulation(El-Magoli et al. 1996).

Data in the same table, it could be noticed that cooking shrinkage percentage of burger samples containing red radish and artichoke were significant lower than the control sample, cooking shrinkage percentage decreased the levels of added red radish and artichoke. Even though this cooking values were lower in burger but they were none significant between the produced beef burger blends with in MA 20, MA30, MA40 and MA50. While the control sample recorded the highest cooking shrinkage (21.02\%). Also data in same table showed that, the lowest cooking shrinkage was noticed in burger prepared from red radish and there were changes in impact of all the tested blends under investigation on shrinkage. These results are in accordance with those found by Oroszvári et al. (2005) and Oroszvári et al. (2006). The retention of the size and shape of beef burger blends which contain several levels of red radish and artichoke during cooking could be due to the binding and stabilizing property of red radish and artichoke fiber.

The water holding capacity of meat is defined as the ability of meat to hold fast to its own or added water during processing. It is considered as an important factor affects on eating quality, tenderness, juiciness, thawing drip and cooking loss of meat (Morsi, 1988). Data in the same table showed the significant increase in (W.H.C) value of all beef burger blends compared to the control sample, the highest value were found in beef burger contained $50 \%$ radish and artichoke

Cooking loss refers to the reduction weight of beef meat during the cooking process (Drummond and Sun, 2005). From the results in table (5) it could be noticed that cooking loss was affected by the water retention level .In this concern the best samples(lowest cooking loss) were MA10 and MR10 blends.

\section{Sensory evaluation:-}

Sensory evaluation of cooked tested burger represented in Table (6). Form results presented in Table (6), it confirmed that MR10, MR20, MR30,MR40,MR50, MA10, MA20, MA30 and control blends possessed the best color, with no significant difference in between, but was significantly differed than the MA50 blend. Sowbhagya et. al. (2005) reported that, color is a vital quality attribute of foods and plays an important role in sensory and consumer acceptance of products. On the other hand, MA40 and MA50 blends had the lowest score of odor and were significantly differed between the other tested burger. 
Table 6. sensory evaluation of the beef burger blends.

\begin{tabular}{|c|c|c|c|c|c|c|c|}
\hline Blends & $\begin{array}{l}\text { Color } \\
(10)\end{array}$ & $\begin{array}{l}\text { Odor } \\
(10)\end{array}$ & $\begin{array}{c}\text { Texture } \\
\text { (10) }\end{array}$ & $\begin{array}{l}\text { Taste } \\
\text { (10) }\end{array}$ & $\begin{array}{c}\text { Tenderness } \\
\text { (10) }\end{array}$ & $\begin{array}{c}\text { Appearance } \\
\text { (10) }\end{array}$ & $\begin{array}{c}\text { Overall } \\
\text { acceptability } \\
(60)\end{array}$ \\
\hline control & $8.9^{\mathrm{ab}}$ & $8.8^{\mathrm{a}}$ & $8.2^{\mathrm{a}}$ & $8.2^{\mathrm{bcd}}$ & $8.4^{\mathrm{ab}}$ & $8.1^{\mathrm{d}}$ & $50.6^{c}$ \\
\hline MR10 & $8.9^{\mathrm{ab}}$ & $8.7^{\mathrm{a}}$ & $8.3^{\mathrm{a}}$ & $9.2^{\mathrm{a}}$ & $8.3^{\mathrm{b}}$ & $9.1^{\mathrm{a}}$ & $52.5^{\mathrm{a}}$ \\
\hline MR20 & $8.9^{\mathrm{ab}}$ & $8.8^{\mathrm{a}}$ & $8.3^{\mathrm{a}}$ & $8.7^{\mathrm{ab}}$ & $9.0^{\mathrm{a}}$ & $8.8^{\mathrm{abc}}$ & $52.5^{\mathrm{a}}$ \\
\hline MR30 & $8.6^{\mathrm{ab}}$ & $8.4^{\mathrm{ab}}$ & $8.1^{\mathrm{ab}}$ & $9.2^{\mathrm{a}}$ & $8.5^{\mathrm{ab}}$ & $9.0^{\mathrm{a}}$ & $51.8^{\mathrm{b}}$ \\
\hline MR40 & $8.5^{\mathrm{ab}}$ & $8.3^{\mathrm{ab}}$ & $7.7^{\mathrm{abc}}$ & $8.7^{\mathrm{ab}}$ & $7.9^{\mathrm{bc}}$ & $8.6^{\mathrm{abc}}$ & $49.7^{\mathrm{d}}$ \\
\hline MR50 & $8.6^{\mathrm{ab}}$ & $8.7^{\mathrm{a}}$ & $8.0^{\mathrm{ab}}$ & $8.7^{\mathrm{ab}}$ & $8.5^{\mathrm{ab}}$ & $8.5^{\mathrm{bcd}}$ & $51.0^{\mathrm{b}}$ \\
\hline MA10 & $8.9^{\mathrm{ab}}$ & $8.8^{\mathrm{a}}$ & $7.7^{\mathrm{abc}}$ & $7.9^{\mathrm{cd}}$ & $8.2^{\mathrm{b}}$ & $8.5^{\mathrm{bcd}}$ & $50.0^{c}$ \\
\hline MA20 & $8.4^{\mathrm{ab}}$ & $8.7^{\mathrm{a}}$ & $7.9^{\mathrm{ab}}$ & $7.7^{\mathrm{d}}$ & $8.3^{\mathrm{b}}$ & $8.2^{\mathrm{d}}$ & $49.2^{\mathrm{de}}$ \\
\hline MA30 & $8.7^{\mathrm{ab}}$ & $8.5^{\mathrm{ab}}$ & $7.8^{\mathrm{ab}}$ & $8.5^{\mathrm{b}}$ & $8.0^{b c}$ & $8.1^{\mathrm{d}}$ & $49.6^{d}$ \\
\hline MA40 & $8.7^{\mathrm{ab}}$ & $8.1^{\mathrm{bc}}$ & $7.3^{\mathrm{bc}}$ & $8.3^{\mathrm{bc}}$ & $7.5^{c}$ & $8.2^{\mathrm{d}}$ & $48.7^{\mathrm{e}}$ \\
\hline MA50 & $7.0^{\mathrm{b}}$ & $8.1^{b c}$ & $7.1^{c}$ & $8.4^{b c}$ & $8.2^{\mathrm{b}}$ & $8.4^{c d}$ & $47.2^{f}$ \\
\hline
\end{tabular}

Mean values within the same colum bearing different superscripts differ significantly $(P<0.05)$.

MR10 $=$ Meat $+10 \%$ Radish, MA10 $=$ Meat $+10 \%$ Artichoke

MR20 $=$ Meat $+20 \%$ Radish,$\quad$ MA20 $=$ Meat $+20 \%$ Artichoke

MR30 $=$ Meat $+30 \%$ Radish,$\quad$ MA30 $=$ Meat $+30 \%$ Artichoke

MR40 $=$ Meat $+40 \%$ Radish,$\quad$ MA40 $=$ Meat $+40 \%$ Artichoke

MR50 $=$ Meat $+50 \%$ Radish,$\quad$ MA50 $=$ Meat $+50 \%$ Artichoke

With respect to the texture of the tested burger, MA40 and MA50 recorded the lowest value of texture compared to the other burger. Also, MR30, MR40, MR50 , MA10, MA20 and MA30 blends were the most consumers preferable with non significant differences. Meanwhile, there were non significant differences between the other tested samples including MA20, MA30, MR10. MR20, MR30, MR50 and control blends. Taste evaluation MR10, MR20, MR30 MR40and MR50 blends were the most preferable by the panelist followed by the MA30, MA40, MR50 and control blends with non significant differences. The results also showed that there were significant differences between burger supplemented with 40 and $50 \%$ of red radish or artichoke for tenderness characteristics compared to other blends. Statistical analysis showed that there was no significant difference between MA20, MA30 and MA40 blends for appearance compared to other blends. Overall acceptability attributes seemed to follow the same pattern of the taste attribute, wherein, there were significant differences among the beef burger blends. However, the blends containing 10, 20 and $30 \%$ red radish scored highest in overall acceptability, but it was significantly differences compared to which contain 40 and $50 \%$ artichoke. In general, the beef 
burger blends showed that the high consumer acceptable with respect to all sensory properties these results agreement with those obtained by Baltacıoglu and Esin,(2012) who reported that the cooking methods were used for chips production from artichoke.

Generally, it could be concluded that the incorporation of red radish and artichoke into beef burger patties, as a good functional and nutritional properties meat replacer, at the tested levels, $10,20,30 \%$ of meat weight used in burger pattie formulation resulted in producing burger patties without detrimental effect on the sensory attributes besides improving physiochemical properties and cooking measurements of the product.

\section{REFERENCES}

1. American Meat Science Association. 1995. Research guidelines for cookery, sensory evaluation and instrumental tenderness measurements of fresh meat, Chicago, IL, 475p.

2. A.O.A.C. 2000. Association of Official Analytical Chemists. In Official Methods of Analyses, Gaithersburg. M.D. 17th ed.

3. Baltacıoğlu, C. and A. Esin. 2012. Chips Production from Jerusalem Artichoke (Helianthus tuberosus L.).Food and Nutrition Sciences., 3 (9):1321-1328.

4. Bansa, S. P. 2011. Healing power of foods, nature's prescription for common diseases. Pustak Mahal, New Delhi.

5. Drummond, L. S. and D. W. Sun. 2005. Feasibility of water immersion cooking of beef joints: Effect on product quality and yield. J. Food Eng., 77: 289-294.

6. El-Magoli, S., S. Laroia and P. Hansen. 1996. Flavor and texture characteristics of low fat ground beef patties formulated with whey protein concentrate. Meat Science 42: 179-193.

7. rary, C.D and R.k. jhnson. 2005. Alimentos, nutricaoe Dietoerapia,11 Edition Sao Paulo:Rocca,p:20-34.

8. Gedrovica, L. and D. Karklina. 2012. Influence of Jerusalem Artichoke Powder on the Nutritional Value of Pastry Products, World Academy of Science, Engineering and Technology, $67: 1239-1241$

9. Honikel, K.O. 1998. Reference methods for assessment of physical characteristics of meat. Meat Science, 49: 447-457

10. Jama, N. V., M. Muchenje, P. E. Chimonyo, K. D. Strydom and J. G. Raats. 2008. Cooking loss components of beef from Nguni,Bonsmara and Angus steers. African Journal of Agricultural Research , 3 (6): 416-420. 
11. López, G., G. Ros, F. Rincón, M.J. Periago, M.C. Martínez and J. Ortuño. 1997. Mineral composition of isolated fiber fractions from artichoke and the effect of phosphate buffer on its structure and mineral content.Food Chemistry, 60(4): 541-547.

12. Lutz , M. C., M. Henríquez and A. Escobarc. 2011. Chemical composition and antioxidant properties of mature and baby artichokes (Cynara scolymus L.) raw and cooked. Journal of Food Composition and Analysis, 24 (1): 49-54

13. Morsi, H. H. 1988. Studies on Freezing Preservation of Meat. Ph. D. Thesis, Food Science and Technology Dept., Faculty of Agric., Cairo Univ., Egypt.

14. Oroszvári, B. k., E . Bayod, I. Sjohölm and E. Tornberg. 2005. The mechanisms controlling heat and mass transfer on frying beef burgers. 2 . The influence of the pan temperature and patty diameter. J. of Food Engineering, 71: 18 - 27.

15. Oroszvári, B. k., E. Bayod, I. Sjohölm and E. Tornberg. 2006. The mechanisms controlling heat and mass transfer on frying beef burgers. III. Mass transfer evolution during frying. J. of Food Engineering, 76: $169-178$.

16. Ou, D. and G.S. Mittal. 2006. Double-sided pan-frying of unfrozen / frozen hamburgers for microbial safety using modeling and simulation. Food Research International, $39: 133-144$.

17. Samaa , M. Elsayed. 2013. Influence of Using Lupine Flour as Binder on Quality Characteristics of Beef Burger Patties. Journal of Applied Sciences Research, 9(6): 3809-3819.

18. Schneeman, B.O. 1999. Fiber, inulin and oligofructose: Similarities and differences. J. Nutr., 129: 1424S-1427S.

19. Sowbhagya, H. B., S. Smitha, S. R. Pathu, N. Krishnamurthy and S. Bhattacharya. 2005. Stability of water-soluble turmeric colorant in an extruded food product during storage. Journal of Food Engineering, 67: 367- 371.

20. SPSS. 1999. SPSS for Windows. Release 10 (October 1999) Standard Version

21. Tchone, M., G. Barwald and C. Mieier. 2005. "Polyphenol oxidases in Jerusalem artichoke (Helianthus tuberosus. L.)". British Food J, 107(9): 693-701.

22. Vibe, B., J. Sidse, K. Ulla, N. Jørn and M. E. Sørensen. 2013.The effect of culinary preparation on carbohydrate composition, texture and sensory quality of Jerusalem artichoke tubers (Helianthus tuberosus L.). LWT - Food Science and Technology, 54 (1): 165-170 
23. Vincenzo, L., A. Paul V. Kroonb and A. Linsalatac. 2009. Globe artichoke: A functional food and source of nutraceutical ingredients. Journal of Functional Foods, 1 (2): 131-144

24. Zhao-liang, L., L. Li-wang and L. Xiao-yan. 2008. Analysis and Evaluation of Nutritional Quality in Chinese Radish (Raphanus sativus L.).Agricultural Sciences in China, 7(7): 823-830.

25. Zoraida, C. Á. , A. Diego, M. Restrepo, M. and R. Cortés. 2011.Vegetable products as source of dietary fiber in the food industry: a review, Revista Facultad Nacional de Agronomía,edellín. 


\title{
تعديل مبتكر للبرجر التقليدي
}

\author{
نصرة احمد عبد الحق صفاء عزت على ناهد لطفى زكى \\ معهد بحوث تكنولوجيا الأغذية - مركز البحوث الزراعية
}

يعتبر البرجر من الوجبات السريعة المفضلة لدى الكثيرين وخاصة الأطفال و المر اهقين

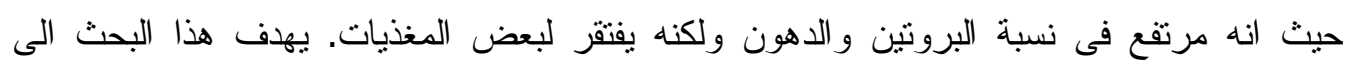

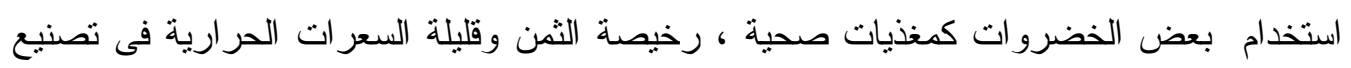

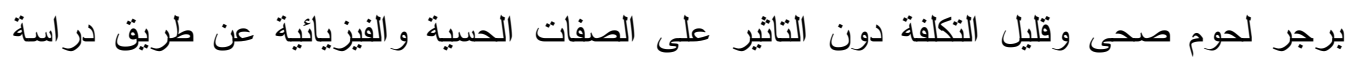

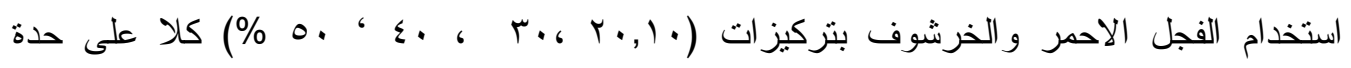

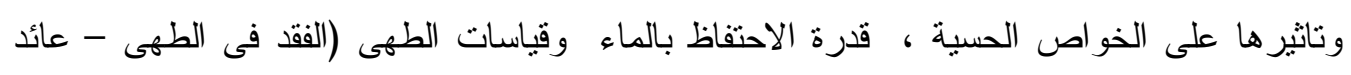

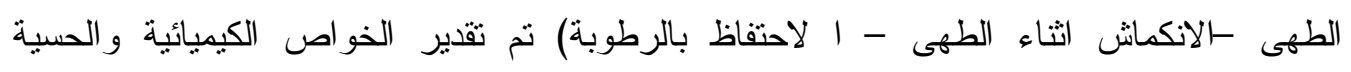
و الفيزيائية للبرجر المصنع • اوضحت النتائج ان بعض الصفات الحسية و الفيزيائية لم تتاثر معنويا

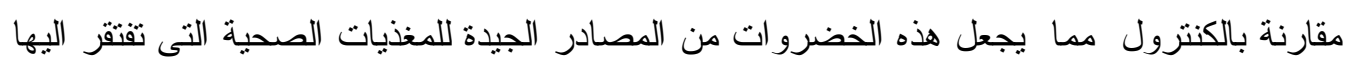

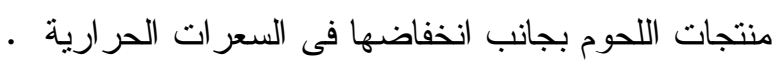

الكلمات الافتتاحية

الفجل الاحمر - الخرشوف - البرجر البقرى - التركيب الكيماوى - قياسات الطهى التقييم الحسى. 